\title{
E-module as an emergency-innovated learning source during the Covid-19 outbreak
}

\author{
Niken Purnamasari ${ }^{1, a} *$, Siswanto Siswanto ${ }^{1, b}$, Shazia Malik ${ }^{2, c}$ \\ ${ }^{1}$ Universitas Negeri Yogyakarta. Jalan Colombo No 1, Yogyakarta 55281, Indonesia \\ ${ }^{2}$ Institute of Education and Research University of the Punjab Lahore. \\ Quaid-i-Azam Campus, Lahore, Punjab, 54590 Pakistan \\ a nikenpurnamasari46@gmail.com; ${ }^{\mathrm{b}}$ siswanto@uny.ac.id; ${ }^{\mathrm{c}}$ shazia.ier@pu.edu.pk \\ * Corresponding Author
}

Received: 7 July 2020; Revised: 20 August 2020; Accepted: 3 September 2020

\begin{abstract}
The COVID-19 pandemic has hugely changed various human activities. This "silentkiller" pande-mic attacks almost every single aspect of life in this entire world. In this case, the writer will focus on the education sector as one of the most damaged fields by the pandemic. Every single of its ele-ments has to be quickly adapted to the situation caused by the COVID-19 attack. Stakeholders are continuing hard to formulate the adaptation that can be taken quickly as the most effective way among the uncertain situation. Shortly, regarding the physical distancing campaigned by the most governments, online learning is then considered as the most possible way to keep the learning pro-cess going with all its strengths and weaknesses. In accordance with the background of the situa-tion, the writer through this study purposed to determine the effectiveness of e-modules as the emergency innovative learning sources in the middle of this COVID-19 outbreak. Online learning is claimed as an effective solution to keep learning to avoid mass gathering that possibly causes the virus to spread at schools. E-modules belong to interactive teaching sources that are capable to facilitate student to learn independently. They still have chances to learn with interesting, practical, and online-accessible to pursue the learning outcomes as good as possible in term of the emer-gency self-learning process. To find out the improvement in students learning outcomes after using the e-module through the online learning process, the data analysis in this study was conducted using a paired sample t-test. At last, the results showed that student learning outcomes could be maintained and even improved after the use of the emodule as an emergency innovative learning source during the COVID-19 outbreak.
\end{abstract}

Keywords: e-module; emergency learning; online learning; learning source; COVID-19 outbreak

How to Cite: Purnamasari, N., Siswanto, S., \& Malik, S. (2020). E-module as an emergencyinnovated learning source during the Covid-19 outbreak. Psychology, Evaluation, and Technology in Educational Research, 3(1), 1-8. doi:http://dx.doi.org/10.33292/petier.v3i1.53

\section{INTRODUCTION}

The world is currently entering a new era in term of technology particularly. Information technology continues to develop into the fourth century of the industrial revolution or better known as industry 4.0. The information technology continues to develop into the all-digital world. On the other hand, humans have freedom in the use of technology. they can control the various conveniences offered by digital technology so that they tend to follow trends or lifestyles that are very closely related to electronic devices in everyday life. Some digital era trends, one of which is the discovery of webbased technology services and social networks that allow users to easily access information and distribute it without being limited by space and time (Setiawan, 2017). Facing the challenges of advancing digital technology in the 4.0 era, education and learning are required to change from basic education to tertiary institutions. Technological progress continues to change, so the teaching methods used in the learning process also change (Dunwill, 2016). Some common changes that occur are giving students online assignments (sharing assignments through certain platforms such as WhatsApp) and collecting 
Psychology, Evaluation, and Technology in Educational Research, 3 (1), 2020, 2

Niken Purnamasari, Siswanto Siswanto, Shazia Malik

them online. Students use software to complete group assignments and upload them through an online portal.

Educational institutions must adapt quickly and effectively to new learning in line with technological advances in the current 4.0 industry revolution. Educational institutions must be able to generate learning that is innovative, flexible, accessible anytime and anywhere. The transformation of online learning must be done quickly to facilitate the learning process across borders and time.

Online learning is learning that uses internet technology that allows teachers and students to learn wherever and whenever outside the classroom (Verawardina et al., 2020). The online learning provides more advantages since it is a learning access which employs the combination between internet connection and technologies (Moore et al., 2011). Thus, it gives the students an opportunity to learn multiple aspects through the online learning, not only the main material itself, but also the technologies embedded in the online learning. Online learning offers more learning flexibility without being limited by distance, space and time. Technology in the field of education must be constantly updated to improve the learning process and interactions between teachers and students, especially online. In online learning, teachers are expected to be able to act as facilitators, collaborators, and mentors. In delivering learning, teachers must be active and innovative to create more interesting learning materials. In addition, online learning can stimulate students towards an independent learning environment which will ultimately provide a new perspective for students in terms of the learning process. The online learning so much relies on technologies such as computers or smartphones and the internet. It should be emphasized that there are several things to consider in the online learning and one of them is the possibility of the smartphone misuse (Firman \& Rahayu, 2020). The students admit that they also use their smartphones to access their social media accounts. It will be so much destructive when they use their smartphone for social media too much instead of online learning. Some studies even showed that it is indicated that the students addicted to the use of smartphone for social media rather that for the online learning. It then generates worries that they will more focus on their social media rather than their online learning process. It even will get worse when they access information without any guidance (Siddiqui \& Singh, 2016). In addition, those who are so much addicted to smartphone tend to have both social and academic issues (Kwon et al., 2013). As a summary, teachers need to arrange the steps to implement the online learning correctly and accurately.

The end of 2019 was a time when human life was disturbed by a virus that spread quickly. The virus first appeared in Wuhan, China (Lee, 2020). The virus became known as COVID-19 (Corona Virus Disease-2019). Transmission was so fast that it infected 216 countries around the world (World Health Organization, 2020) and finally designated WHO as a global pandemic with positive cases of 5,488,825 (update: 27-05-2020). COVID-19 emerged in Indonesia since the beginning of March until now has infected 23,851 people confirmed positive (Pemerintah Republik Indonesia, 2020). Various aspects of life have changed due to COVID-19.

Various government policies and responsiveness in minimizing the impact of COVID-19 have been carried out. In order to reduce the level of spread of this virus, the government imposed PSBB (Large-Scale Social Restrictions) in some red zone areas. Various policies issued by the government to limit the spread of this virus have an impact on various aspects of life, one of which is the impact in the world of education.

Social and physical distancing policies undertaken by local governments greatly affect the conditions of learning from elementary to higher educations. Various schools are closed to reduce the crowd which can increase the spread of COVID-19, while on the other hand, learning must still be carried out. As a result, face-to-face learning is abolished. The COVID-19 outbreak demanded all elements of education to carry out remote learning that had never previously been carried out generally (Sun et al., 2020). Students, teachers and parents must adapt to these conditions, considering the time, location, and distance become a big problem during this pandemic (Kusuma \& Hamidah, 2020). The highlight solutions offered today are online learning. In spite of the outbreak that is happening, students must still get their rights in terms of education, even if it should be done remotely (The United Nations Educational Scientific and Cultural Organization, 2020). There-fore, online learning is so much needed that teaching and learning activities can continue to run.

Teachers, students, and parents have collectively the challenges to continue implementing active learning even though the schools are closed. Teachers as one of the key elements of education are enforced to facilitate students to continue learning, provide the learning materials, and even formulate 
Psychology, Evaluation, and Technology in Educational Research, 3 (1), 2020, 3

Niken Purnamasari, Siswanto Siswanto, Shazia Malik

the assessment systems so that students' learning outcomes can be On the other hand, COVID-19 ironically has a positive impact in pioneering online learning simultaneously. Teachers as educators and key elements in the classroom learning process must innovatively migrate from face-to-face (traditional) learning to online-based learning (Bao, 2020; Basilaia \& Kvavadze, 2020). Teachers and educators should not stutter with online learning to keep abreast of the unlimited industrial revolution 4.0, especially related to technology in the field of education. Online learning can also be effective if the teacher can actively motivate and provide understanding to students, so that they will understand the concepts and goals of independent learning and follow instructions given by the teacher in the midst of this COVID 19 pandemic. Online learning is considered the most effective way to carry out learning even though teachers and students are in different places (Verawardina et al., 2020). At least, these conditions can still provide opportunities for students to continue to get updated and gain knowledge.

In the midst of this pandemic COVID-19 condition, it is urgent to make various learning innovations related to the adaptation and utilization of available technology to support the learning process (Ahmed et al., 2020). The practice requires educators and students to interact and transfer knowledge online. Online learning can utilize various platforms available in the form of applications, websites, social networks, and learning management systems (Gunawan et al., 2020). These various platforms are one of the media used to support online learning, while the transfer of knowledge must still be carried out from educators to students.

Teachers must adapt different teaching strategies according to students' needs (Abad, 2006). It is very important for teachers to have skills in choosing the right strategy in the context of a particular lesson (Salandanan, 2005). The learning process through the use of audio-visual learning media is arguably able to increase the students' learning motivation (Sarwinda et al., 2020). Teachers must have knowledge and be keen about how students learn to formulate appropriate teaching techniques and strategies in online learning. Successful classroom teaching depends on teaching techniques (Gregorio, 1976). Online learning techniques during this COVID-19 pandemic must be highly considered by teachers. Learning activities of students through online learning must continue with the right design and organization. Otherwise, it will only waste time and effort and will not achieve satisfactory results.

However, amid this COVID-19 attack and the limitations of online learning, to be honest it cannot be expected that students will remain at peak performance in learning. The availability of adequate internet is a fundamental challenge for students. Most students access the internet using cellular services. From the pre-survey results, $15 \%$ of students from this study population experienced weak signal constraints. When the home-learning policy to suppress the spread of co-19 is imposed by the government, they must go to a supportive place to get a signal to take part in online learning.

Another challenge that must be faced is related to costs. Based on students' statements, they must spend 50\% more to buy the data quota. In this case, the school has provided a data package that is distributed to students. This is expected for students to be able to smoothly follow online learning. Apart from that, other challenge is that most students have difficulty in receiving lessons due to the limitations of communication carried out online. Various teaching techniques and strategies have been used to improve the teaching-learning process in the pandemic COVID-19 period which is full of limitations. Among all the limitations of online learning, one of the most efficient and effective methods for giving understanding to students is to use e-modules that have been designed by teachers according to the needs of students. The use of modules can help students to learn in gaining knowledge, skills, and information without being accompanied by a teacher directly (Lim, 2016). Besides that the module is also a unit of independent learning activities that is used as a learning aid for students (Guido, 2014). While e-modules are modules that are packaged in electronic form so that it is more practical and efficient, and is presented through the display of animation, text, and images (Abidin \& Walida, 2018; I Made Astra, 2018). These various opinions are the reason for researchers to know the effectiveness of using e-modules as a medium for online emergency learning during the COVID-19 pandemic. The difference between this research and previous research lies in the situation of e-module implementation. Furthermore, this study investigates the effectiveness of the use of emodules in online learning which is still rarely done and is carried out amid the COVID-19 pandemic. 


\section{Psychology, Evaluation, and Technology in Educational Research, 3 (1), 2020, 4}

Niken Purnamasari, Siswanto Siswanto, Shazia Malik

\section{METHOD}

This research was conducted at SMK Muhammadiyah Wonosari, Alun-Alun Barat No.10 street, Wonosari, Gunungkidul Regency, Special Region of Yogyakarta. This study involved all students in grade 10 accounting and finance programs, totaling 52 students as respondents. The study employed the pre-experimental test using one group pretest-posttest design. In other words, this research was conducted by comparing the students' conditions before using the e-module and the conditions thereafter.

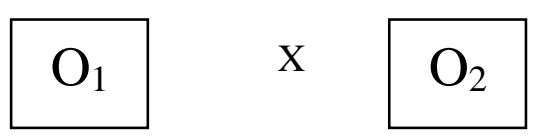

Figure 1. A One-Group Pretest-Posttest Research Design (Sugiyono, 2017)

Using this research design, researchers will try to approach whether e-modules are indeed the most effective learning resources for use in online distance learning with all the advantages and disadvantages, especially amid the current COVID-19 attacks. Conclusions regarding the effectiveness of this e-module will be known through various assessment instruments for learning achievement tests. The instruments in this study include the e-module itself, pre-test, and post-test. For information, the e-module that will be used in this study has been previously validated by media experts, material experts, and learning practitioner teachers. The pretest and posttest used as an effectiveness analysis in this study have also been validated by material experts.

Because almost the whole world is currently being hit by a COVID-19 pandemic attack. this research had to be done online, in line with the policies to avoid mass gathering, to obey the physical distancing, and to involve online learning processes as well as to keep the education running. Online learning and the implementation of pretest and posttest is done through a web-based platform, learning management system (LMS) owned and managed by SMK Muhammadyah Wonosari. Pretest is carried out before students get learning through the e-module. The pretest is carried out to determine the initial abilities of students before getting the effect of e-module implementation. After having the pretest, the students were then taught by using the e-module in the context of online learning. An assessment is then carried out after the implementation of online learning using e-modules to determine the student's final ability as indicated by the results/scores of the post-test. The various values and data are then analyzed using paired sample t-test. The aim is to determine whether there is a difference between the pretest and posttest scores.

\section{RESULTS AND DISCUSSIONS}

Various data needed in this study were collected both before and after the online learning process. Data collected before the learning process is used to determine students' initial abilities. While the data collected after the learning process aims to investigate whether there are differences between the initial ability and student learning outcomes after using the e-module through the online learning process, especially during the Large-Scale Social Restrictions period due to the COVID-19 pandemic outbreak. A summary of the data that is the result of the Pretest-Posttest obtained before and after the use of e-modules through the online learning process can be seen in Table 1.

Table 1. Results of the Pretest-Posttest

\begin{tabular}{lccc}
\hline & Description & Pre-test & Post-test \\
\hline Minimum Score & & 30.0 & 50.0 \\
Maximum Score & 87.5 & 97.5 \\
Mean Score & 56.16 & 75.81 \\
\hline
\end{tabular}

(Source: Research Data Analysis)

In general, the pretest shows the results or scores of students who are classified as low. Based on the analysis of the pretest data, the lowest score of students was 30.0; the highest score of students was 87.5, and their average score was 56.16. Based on these data, it can be reflected that in general, the average students' score has not yet reached the minimum competence passing grade. Furthermore, students are treated through an online learning process using the e-module. Implementation of online learning is done by providing a stimulus in the form of student tasks that must be submitted punctually 
at the end of online learning activities. These activities were carried out in six meetings. Meanwhile, the results of the posttest analysis of the students after using the e-module showed an increase in learning outcomes as indicated by the posttest scores. The results of the students' posttest analysis after using the e-module showed the students' lowest score of 50.0, the highest score of 97.5, and the students' average score of 75.81. At last, in accordance with the posttest scores, the average value has accomplished the minimum competence passing grade.

Furthermore, researchers conduct an analysis or test to determine the effect or effectiveness of the use of e-modules by the students of accounting and financial programs on their learning outcomes. The test was carried out using paired sample t-test which aims to determine the condition (ability) of students between before and after treatment. However, before being analyzed using a paired sample ttest, the pretest and posttest score data were subjected to a prerequisite test, namely the normality test and the homogeneity test as well.

The normality test is carried out to find out whether the data is normally distributed or not. Normal distribution data is an absolute requirement before hypothesis testing is performed. The calculation of normality test is based on a hypothesis:

Ho: data obtained from populations that are normally distributed

Ha: data obtained from populations that are not normally distributed

The normality test can be seen in the test of normality in the Kolmogorov-Smirnov section on SPSS 22. 'Ho' is accepted if the significance value is more than 0.05 . Thus, if the significance value is less than 0.05 , then 'Ho' is rejected. As a result, the data is not normally distributed. To figure it out, the normality test results can be observed in Table 2.

Table 2. The Normality Test on the Students' Learning Outcomes

\begin{tabular}{|c|c|c|c|c|}
\hline \multirow[b]{2}{*}{ Data } & \multicolumn{2}{|c|}{ Sign $(p)$} & \multirow{2}{*}{ Condition } & \multirow{2}{*}{ Criteria } \\
\hline & Pretest & Posttest & & \\
\hline Learning Outcomes & 0,200 & 0,117 & $p>0,05$ & normal \\
\hline
\end{tabular}

(Source: Research Data Analysis)

Based on the data analysis in Table 2, the pretest significance value reached 0.200 which means that Ho was accepted, thus the data was normally distributed. Furthermore, the posttest significance value of 0.117 indicates that Ho was accepted, thus the data was also normally distributed. In accordance, it can be concluded that overall, the data in the form of learning outcomes (test scores) are normally distributed.

Homogeneity test is performed to find out whether the research subject data is from a homogeneous population or not. In this study, the homogeneity testing is based on the following hypothesis:

Ho: data obtained from one population or homogeneous

$\mathrm{Ha}$ : data obtained from different populations or not homogeneous

Ho is acceptable if the significance value is ore than 0.05 . If the significance value is less than 0.05 , the Ho is automatically rejected, and the data are not homogeneous. The homogeneity test result is showed in the Table 3.

Table 3. The Homogeneity Test Result on The Students' Learning Output

\begin{tabular}{ccccc}
\hline \multirow{2}{*}{ Data } & \multicolumn{2}{c}{ Sign $(\mathrm{p})$} & \multirow{2}{*}{ Condition } & \multirow{2}{*}{ Criteria } \\
\cline { 2 - 3 } & Pretest & Posttest & & $\mathrm{p}<0,05$ \\
\hline Learning Outcomes & 0,000 & 0,000 & & Not Homogeneous \\
\hline
\end{tabular}

(Source: Research Data Anaylsis)

Based on the analysis of Table 3, the pretest significance value of 0.000 and posttest of 0.000 all values less than 0.05 means that Ho is rejected, and Ha is accepted, then the data is not homogeneous. It can be concluded that the value of the learning achievement test data is not homogeneous. Homogeneity is not an absolute requirement in this test, so data that is not the same or homogeneous can still be tested paired sample $t$ test. Thus, the requirements for paired sample $t$ test have been fulfilled.

The next step in this research is the implementation of a paired sample t-test. A paired sample ttest was conducted to determine the margin of improvement in student learning outcomes between before and after using the e-module in the online learning process, especially during the current COVID- 
Psychology, Evaluation, and Technology in Educational Research, 3 (1), 2020, 6

Niken Purnamasari, Siswanto Siswanto, Shazia Malik

19 pandemic. This test is administered to see the difference of the students learning outcomes before and after the given treatment. Followingly, the hypothesis formulation from a paired sample t-test is detailed below.

Ho: There is no difference in learning outcomes before and after the treatment using the e-module through the online learning process during the current COVID-19 pandemic.

Ha: There is a difference in learning outcomes before and after the treatment using the e-module through the online learning process during the current COVID-19 pandemic.

The decision making criteria used in this calculation are firstly, if the significance value (p)> 0.05 , Ho is accepted, or in other words, it can be stated that there is no difference in learning outcomes before and after treatment is given using the e-module. Secondly, if the significance value $(p)<0.05$, Ho is rejected, and Ha is accepted. In other words, it can be stated that there are differences in learning outcomes before and after the treatment using the e-module. A summary of the results of the paired sample t-test analysis can be seen in Table 4.

Table 4. The Result of Paired Sample t-Test

\begin{tabular}{cccc}
\hline Data & Sign $(\mathrm{p})$ & Condition & Criteria \\
\hline Pair 1 Pretest-Posttest & 0.000 & $\mathrm{P}<0.05$ & Ho is rejected, and Ha is accepted \\
\hline (Source: Research Data Analysis) & & &
\end{tabular}

(Source: Research Data Analysis)

Based on the calculation results in Table 4 , it was obtained that the sign value (p) $<0.05$, which means that Ho was rejected, and Ha is accepted. Thus, it can be concluded that there are differences in learning outcomes before and after the treatment or action using e-modules through the online learning process during the current COVID-19 outbreak.

In general, the e-module is one of the teaching materials developed based on an analysis of the needs of students. It also has the characteristics of supporting the independent learning process, and can be accessed anytime, anywhere. This fact is very suitable to be applied during COVID-19 which requires the implementation of the remote learning through various online platforms. The e-module is then considered the most effective and efficient solution. The response of teachers and students to the application of e-modules is very positive to help the learning process (Priatna et al., 2017).

Another expert, Daryanto (2013) states that by using media in the form of learning modules, the learning process can be done more interestingly and interactively. The quality of learning obtained by students can be improved. Flexibility is one that is offered by the online e-module because the learning process can be carried out anywhere and anytime. Furthermore, specifically the learning attitudes of students can also be improved. The e-module makes it easy for students to understand learning material so that it can improve learning outcomes (Maswan \& Muslimin, 2017). Another research held by Ansori (2018) also revealed that the use of modules can improve the students' learning outcomes in terms of the cognitive, psychomotor, and affective abilities as well.

\section{CONCLUSION}

Finally, based on the results of research that has gone through comprehensive analysis and indepth discussion, it can be concluded that the use of the e-module in the online learning process is an effective approach, despite all its strengths and weaknesses, to support distance learning online policy far in the midst of the current COVID-19 pandemic attack. Effective in this case is at least still able to help students learn the concepts of learning materials that are designed and provided by teachers through online distance learning. Although in general the conclusions of this study are only based on data taken from the pre-test and post-test online learning processes, learning using the e-module is still much better than not using the e-module at all. Furthermore, the discussion in this study also indicates that the use of e-modules through the online learning process is also effective in improving student learning outcomes without ignoring all the limitations of the COVID-19 pandemic.

On the other hand, the COVID-19 outbreak which paralyzed various aspects including the world of education has simply forced the readiness of stakeholders to immediately make the transition from the classroom learning process to the online learning process distance. In line with this fact, this research proves that the learning process transition was successfully carried out by utilizing the learning resources in the form of e-modules. In the future, various learning systems and new skills experienced by teachers, students, and schools can continue to be implemented and developed after the 


\section{Psychology, Evaluation, and Technology in Educational Research, 3 (1), 2020, 7}

Niken Purnamasari, Siswanto Siswanto, Shazia Malik

COVID-19 pandemic attack as an alternative learning process when it is not possible to be done directly in the classroom, without prejudice to the aspects of effectiveness and efficiency of the learning process itself. All parties should be much more responsible to the remote learning process. The teachers must be aware of the remote (online) learning process and responsive to it in a new perspective. In advance, the students also realize the significance of the independent learning as a brandnew skill. In the end, the writer has some suggestions regarding the online learning process in the future after the COVID-19 outbreak, namely by arranging and designing all aspects of learning as efficiently and effectively as possible, for example rearranging the timeline so that it can run effectively, preparing new tasks on all subjects that constitute additional work, and preparing any strategy to avoid cheating that possibly be done by students since the online learning process is also considered as a self-learning process.

\section{REFERENCES}

Abad, M. L. I. (2006). Training needs \& performance of engineering math teacher in the state colleges of region VIII: Inputs to a proposed in-service training program. Leyte Institute of Technology.

Abidin, Z., \& Walida, S. El. (2018). Research article module as the alternative to transformation geometry learning media to support student's learning autonomy and competence. Asian Journal of Science and Technology, 09(02), 7447-7451.

http://vipspublisher.com/journalajst.com/sites/default/files/issues-pdf/5345.pdf

Ahmed, S., Shehata, M., \& Hassanien, M. (2020). Emerging faculty needs for enhancing student engagement on a virtual platform. MedEdPublish, 9(1).

https://doi.org/10.15694/mep.2020.000075.1

Ansori, M. (2018). Pengembangan modul akuntansi berbasis scientific approach sebagai pendukung implementasi Kurikulum 2013 [Universitas Negeri Yogyakarta]. https://eprints.uny.ac.id/61787/

Bao, W. (2020). COVID-19 and online teaching in higher education: A case study of Peking University. Human Behavior and Emerging Technologies, 2(2), 113-115. https://doi.org/10.1002/hbe2.191

Basilaia, G., \& Kvavadze, D. (2020). Transition to online education in schools during a SARS-CoV-2 Coronavirus (COVID-19) pandemic in Georgia. Pedagogical Research, 5(4). https://doi.org/10.29333/pr/7937

Daryanto, D. (2013). Menyusun modul bahan ajar untuk persiapan guru dalam mengajar. Gaya Media.

Dunwill, E. (2016). 4 changes that will shape the classroom of the future: Making education fully technological. E-Learning Industry. https://elearningindustry.com/4-changes-will-shapeclassroom-of-the-future-making-education-fully-technological

Firman, F., \& Rahayu, S. (2020). Pembelajaran online di tengah pandemi Covid-19. Indonesian Journal of Educational Science (IJES), 2(2), 81-89. https://doi.org/10.31605/ijes.v2i2.659

Guido, R. M. D. (2014). Evaluation of a modular teaching approach in materials science and engineering. American Journal of Educational Research, 2(11), 1126-1130. https://doi.org/10.12691/education-2-11-20

Gregorio, H. C. (1976). Principles and methods of teaching. Garotech Publishing.

Gunawan, G., Suranti, N. M. Y., \& Fathoroni, F. (2020). Variations of models and learning platforms for prospective teachers during the COVID-19 pandemic period. Indonesian Journal of Teacher Education, 1(2), 61-70. https://journal.publication-center.com/index.php/ijte/article/view/95

I Made Astra, I. J. S. V. S. S. R. (2018). Development of e-module based on problem based learning (PBL) on heat and temperature to improve student's science process skill. TOJET: The Turkish Online Journal of Educational Technology, 17(3), 26-36. http://www.tojet.net/articles/v17i3/1733.pdf

Kusuma, J. W., \& Hamidah, H. (2020). Perbandingan hasil belajar matematika dengan penggunaan platform Whatsapp Group dan webinar Zoom dalam pembelajaran jarak jauh pada masa 


\section{Psychology, Evaluation, and Technology in Educational Research, 3 (1), 2020, 8}

Niken Purnamasari, Siswanto Siswanto, Shazia Malik

pandemik Covid 19. JIPMat, 5(1). https://doi.org/10.26877/jipmat.v5i1.5942

Kwon, M., Lee, J.-Y., Won, W.-Y., Park, J.-W., Min, J.-A., Hahn, C., Gu, X., Choi, J.-H., \& Kim, D.J. (2013). Development and validation of a Smartphone Addiction Scale (SAS). PLoS ONE, 8(2), e56936. https://doi.org/10.1371/journal.pone.0056936

Lee, A. (2020). Wuhan novel coronavirus (COVID-19): why global control is challenging? Public Health, 179, A1-A2. https://doi.org/10.1016/j.puhe.2020.02.001

Lim, E. J. A. (2016). Effectiveness of modular instruction in word problem solving of BEED students. IOSR Journal of Mathematics (IOSR-JM), 12(5), 2278-5728. https://doi.org/10.9790/57281205075965

Maswan, M., \& Muslimin, K. (2017). Teknologi pendidikan: Penerapan pembelajaran yang sistematis. Pustaka Pelajar.

Moore, J. L., Dickson-Deane, C., \& Galyen, K. (2011). E-Learning, online learning, and distance learning environments: Are they the same? The Internet and Higher Education, 14(2), 129-135. https://doi.org/10.1016/j.iheduc.2010.10.001

Pemerintah Republik Indonesia. (2020). Situasi virus COVID-19 di Indonesia. Satuan Tugas Penanganan Cobid-19. https://covid19.go.id/peta-sebaran

Priatna, I. K., Putrama, I. M., \& Divayana, D. G. H. (2017). Pengembangan e-modul berbasis model pembelajaran project based learning pada mata pelajaran videografi untuk siswa kelas X desain komunikasi visual di SMK Negeri 1 Sukasada. Jurnal Nasional Pendidikan Teknik Informatika (JANAPATI), 6(1), 70. https://doi.org/10.23887/janapati.v6i1.9931

Salandanan, G. G. (2005). Teaching and the teacher. Adriana Printing Co., Inc.

Sarwinda, K., Rohaeti, E., \& Fatharani, M. (2020). The development of audio-visual media with contextual teaching learning approach to improve learning motivation and critical thinking skills. Psychology, Evaluation, and Technology in Educational Research, 2(2), 98. https://doi.org/10.33292/petier.v2i2.12

Setiawan, W. (2017). Era digital dan tantangannya. Seminar Nasional Pendidikan, 1-9. http://eprints.ummi.ac.id/151/

Siddiqui, S., \& Singh, T. (2016). Social media its impact with positive and negative aspects. International Journal of Computer Applications Technology and Research, 5(2), 71-75. http://ijcatr.com/archives/volume5/issue2/ijcatr05021006.pdf

Sugiyono, S. (2017). Metode penelitian pendidikan (Pendekatan kuantitatif, kualitatif, dan $R \& D$ ). Alfabeta.

Sun, L., Tang, Y., \& Zuo, W. (2020). Coronavirus pushes education online. Nature Materials, 19(6), 687-687. https://doi.org/10.1038/s41563-020-0678-8

The United Nations Educational Scientific and Cultural Organization. (2020). Distance learning solution. UNESCO. https://en.unesco.org/covid19/educationresponse/solutions

Verawardina, U., Asnur, L., Lubis, A. L., Hendriyani, Y., Ramadhani, D., Dewi, I. P., Darni, R., Betri, T. J., Susanti, W., \& Sriwahyuni, T. (2020). Reviewing online learning facing the Covid-19 outbreak. Talent Development and Excellence, 12(SpecialIssue3), 385-392.

https://www.iratde.com/index.php/jtde/article/view/281

World Health Organization. (2020). Coronavirus disease (COVID-2019) situation reports. 